\title{
INTEGRASI ALIRAN PEMIKIRAN KEISLAMAN: PEMIKIRAN QADARIYAH DAN JABARIYAH YANG BERSANDAR DIBALIK LEGITIMASI AL-QUR'AN
}

\author{
Suhaimi \\ Universitas Madura Pamekasan \\ Email: suhaimi.dorez@gmail.com
}

\begin{abstract}
Abstrak: Artikel ini sengaja penulis angkat dalam rangka untuk memperdalam khasanah keilmuan yang berkaitan dengan persoalan aliranaliran pemikiran yang pernah berkembang pada masa pasca-wafatnya Rasulullah saw., khususnya Qadariyah dan Jabariyah. Disamping itu penulis juga tertarik terhadap pemikiran kedua aliran tersebut yang saling bertentangan secara ekstrim.

Aliran Qadariyah berpendapat bahwa manusia mempunyai kebebasan berkehendak dan melakukan perbuatan, tidak ada sangkutpautnya dengan kehendak Allah. Namun justru Jabariyah berpendapat lain, bahwa manusia tidak mempunyai daya dan kehendak apapun, semuanya karena atas kehendak Allah. Oleh karenanya dua pendapat yang berseberangan ini perlu adanya integrasi pemikiran agar dapat ditemukan titik temu keduanya.

Adapun metode yang dipakai dalam artikel ini dilakukan dengan cara mengkaji literatur-literatur yang berkaitan dengan sejarah pemikiran Qadariyah dan Jabariyah yang kemudian dilakukan semacam interpretasi baik secara objektif maupun subjektif.
\end{abstract}

Kata kunci: Qadariyah, Jabariyah dan Integrasi Pemikiran.

Abstract: This article is deliberately adopted by the author in order to deepen the scientific treasures related to the problems of thought of schools that have developed in the post-Prophet Muhammad era, especially Qadariyah and Jabariyah. Besides that, the writer is also interested in the thoughts of the two schools that are in extreme conflict.

The Qadariyah sect argues that humans have the freedom to desire and do deeds, nothing to do with God's will. But instead Jabariyah argues differently, that humans do not have any power and will, all because of God's will. Therefore, these two opposing opinions need integration of ideas so that they can be found at the meeting point.

The method used in this article is carried out by reviewing the literature relating to the history of Qadariyah and Jabariyah thoughts which are then carried out in an objective and subjective interpretation. 
Keywords: Qadariyah, Jabariyah and Thought Integration.

\section{Prolog}

Dalam sejarah Islam telah banyak dijelaskan tentang beberapa aliran atau sekte yang perhubungan dengan persoalan teologi (pahampaham keagamaan).Aliran yang dimaksud meliputi golongan Syi'ah, Khawārij, Qadariyah, Jabariyah, Murji'ah, Mu'tazilah, al-Azāriqah ${ }^{1}$ dan golongan-golongan lain yang masing-masing memiliki visioner atau pandangan yang berbeda mengenai berbagai persoalan yang salah satunya yaitu terkait masalah teologi.

Persoalan teologi yang diperdebatkan oleh mereka dapat menyangkut masalah sifat dan keesaan Allah, masalah qaḍā' dan qadar dan keadilan Allah, masalah janji (al-wa'du) dan ancaman (wa'id) dan Asma Allah, masalah wahyu, akal dan masalah kenabian serta persoalan lainnya yang dianggap perlu diperdebatkan. ${ }^{2}$ Masalah-masalah tersebut diperdebatkan dengan pandangan yang berbedaatau adakalanya terdapat persamaan persepsi antara masing-masing golongan.Namun pendapat yang dikemukakan sama-sama memiliki dasar yang kuat baik dari perspektif dalil (naqIi) maupun akal (aq/i).

Adapun tentang banyaknya sekte yang berkembang dalam sejarah kehidupan manusia tidak dapat ditentukan secara pasti, karena masingmasing penulis buku atau literatur mempunyai pandangan yang berbeda. Adakalanya memahami suatu aliran tertentu disebut sebagai sekte, dan ada kalanya juga memandang lain bahwa aliran tersebut bukan merupakan sekte, hal ini tergantung pada perspektif mereka masing-masing. ${ }^{3}$

Proses timbulnya beberapa aliran sebenarnya tidak terlepas dari persoalan politik pasca wafatnya Rasulullah saw., bahkan dapat dinyatakan pula bahwa pemicunya adalah persoalan khalifah yang akan menggantikan Rasul. Pada awalnya terjadi perdebatan antara kaum Muhajirin dan kaum Anșar, namun hal inidapat diselesaikan dengan baik. Akan tetapi setelah itu muncul lagi gejala perpecahan antara AҐi bin Abī Țālib dengan Uthmān bin Affān. Selanjutnya yang menjadi titik klimaks konflik yaitu terbunuhnya Uthmān bin Affān pada saat menjabat sebagai khalifah ketiga. ${ }^{4}$ Peristiwa

\footnotetext{
${ }^{1}$ Golongan ini merupakan salah satu bagian dari firqahKhawārij, pengikut Nāfi' ibn al-Azrāq al-Hanafi al-Bakrī wafat tahun 65 Hijriyah. Pernah menimba ilmu dari Ibn Abbās. Mereka adalah firqah Khawārij yang paling banyak pengikutnya dibanding firqah sempalan yang lainnya. Abū Manșūr Abdu al-Qāhir ibn Ṭāhir al-Baghdādì, al-Farqu bayna al-Firāq, (Mesir: Maktabah Ibn Sinā, t.th), 78.

${ }^{2}$ Al-Shahrastanī, Al-Milāl wa Al-Nihāl, Terj. Asywadie Syukur (Surabaya: PT. Bina Ilmu, 1995), 4.

${ }^{3}$ Ibid., 4.

${ }^{4}$ Yusran Asmuni, Dirāsah Islāmiyyah II (Jakarta: PT. Grafindo Persada, 1996), 65.
} 
inilah yang menyebabkan berkembangnya sekte-sekte dalam teologi yang dalam istilah sering disebut denganMadzhab dalam Ilmu Kalam.

Pada tulisan ini tidak akan membahas secara konprehensif tentang penyebab munculnya berbagai sekte atau macam-macam sekte, namun secara spesifik akan membahas masalah golongan Qadariyah dan Jabariyah. Berikut akan dibahas tentang tokoh-tokohnya, pandangannya terhadap persoalan teologi, macam-macamnya serta perkembangannya dalam sejarah pemikiran ilmu kalam. Karena kedua golongan tersebut sangat sering diperbincangkan dalam dikalangan umat muslim, bahkan sebagian dari mereka ada yang mengadopsi pemikiran dan pendapat-pendapatnya untuk dijadikan pedoman dalam melakukan amalan-amalan keagamaan.

\begin{abstract}
Aliran Qadariyah
Bilamana mengkaji dan menganalisis persoalan konstelasi politik pada masa khalifah, spesifik pada masa pemerintahan Uthmān Ibn Affān yang merupakan puncak terjadinya konflik antar-umat Islam dalam memperebutkan kursi kekuasaan baik di tingkat khalifah maupun dibawahnya (gubernur), menyusul dengan terbunuhnya Khalifah Uthmān, maka menimbulkan asumsi bahwa mungkin hal tersebut yang menjadi cikal bakal tumbuhnya paham Qadariyah dan Jabariyah. ${ }^{5} \mathrm{Hal}$ ini ditengarai sebagian umat Islam telah berani membuat analisis tentang pembunuhan Uthmān tersebut, apakah si pembunuhnya berdosa atau tidak.Dan yang menggerakkan tangan si pembunuh itu apakah manusia sendiri atau dari Tuhan.

Madzhab Qadariyah muncul sekitar tahun 70 H/689 M. Tokoh utama madzhab Qadariyah adalah Ma'bad al-Juhani dan Ghailān alDimashqi. Ma'bad pernah berguru pada Hasan al-Bașrī bersama Wạșil ibn Ațā', jadi beliau termasuk tabi'in atau generasi kedua setelah Nabi. Sedangkan Ghailan semula tinggal di Damaskus.Ghailan seorang yang ahli dalam berpidato sehingga banyak orang yang tertarik dengannya.Kedua tokoh ini yang menyebarkan paham-paham Qadariyah.

Kedua tokoh tersebut mati dibunuh, Ghailan dibunuh pada masa Hisham Ibn Abdul Malik (724-743 M), dibunuhdengan diberikan hukuman mati oleh Hisyam yang sebelumnya diadakan perdebatan antara Ghailan dan al-Awzà'i. Ma'bad dibunuh karena dituduh terlibat dalam pemberontakan bersama dengan Abd al-Rahmān al-Aṣ'aț, Gubernur Sajistan dalam menentang kekuasaan bani Ummayah.Dalam pertempuran
\end{abstract}

\footnotetext{
${ }^{5}$ Ibid., 59.
} 
dengan al-Hajjāj Ibn Yūsuf al-Thaqafì (orang suruhan Khalifah Abd alMālik Ibn Marwān), Ma'bad mati terbunuh tahun $80 \mathrm{H}^{6}{ }^{6}$

Kedua tokoh golongan Qadariyah yaitu: Ma'bad al-Juhaini dan Ghailan al-Dimashqi yang menyebarkan paham-paham Qadariyah kepada umat Islam pada masa itu, sehingga mengalami perkembangan ke berbagai daerah terutama Iraq dan Iran. Ma'bad menyebarkan pahamnya di Iraq dalam waktu yang relatif singkat tetapi dengan hasil yang sangat gemilang.Banyak orang yang tertarik dan menganut pahamnya.

Ghailan al-Dimashqi melanjutkan penyebaran paham Qadariyah di Shām tepatnya di daerah Damashkus, sehingga mengalami perkembangan yang cukup pesat.Namun sebelumnya masih mendapat tantangan dari Khalifah Umar Ibn Abd al-'Azīs. Banyak sekali pengikut dari paham ini sampai kedua tokoh tersebut wafat yang kemudian digantikan oleh para pengikut-pengikutnya.?

Dalam perkembangannya penganut paham Qadariyah adalah Mu'tazilah.Paham Mu'tazilah inilah yang menjadi penyambung ajaran Qadariyah, karena dilihat dari perkembangan pemikirannya mengalami kesamaan dari keduanya, walaupun terdapat sudut pandang yang membedakan secara spesifik. ${ }^{8}$

Menurut pandangan KH.Ach. Masduki, seorang tokoh NU yang pernah menjabat sebagai Wakil Rōis ' $\bar{A}$ m PWNU Jatim, menyatakan bahwa paham dari golongan Qadariyah ini juga merupakan sebagian dari paham Mu'tazilah.Oleh karena itu golongan Qadariyah juga boleh dinamakan Mu'tazilah Qadariyah. ${ }^{9}$

Istilah Qadariyah berasal dari pengertian bahwa manusia terpaksa tunduk pada qadar atau kadar Tuhan. Dalam bahasa Inggrisnya paham ini dikenal dengan namafree will dan free act. ${ }^{10}$ Secara bahasa berasal dari Qadr yang artinya kuasa atau berkuasa.Maksudnya manusia mempunyai kekuasaan untuk mengatur dan menentukan berbuatannya sendiri.

Qadariyah adalah orang-orang yang meyakini bahwa manusia mampu menciptakan perbuatannya sendiri, baik perbuatan terpuji maupun berbuatan buruk, dan tidak ada intervensi Allah. Dengan kata lain bahwa paham Qadariyah tidak mempercayai adanya takdir (ketentuan) Allah yang telah ditetapkan pada zaman azali, karena seluruh perbuatan, tingkah laku

\footnotetext{
${ }^{6}$ Harun Nasution, Teologi IslamAliran-Aliran Sejarah Analisa Perbandingan (Jakarta: Universitas Indonesia, 2002), 34.M. Romli Arief, Kajian Ahl al-sunnah Waal-Jamā'ah Tinjauan Historis (Jombang: Unhasy Press, 2005), 75.

${ }^{7}$ Yusran Asmuni, Dirāash Islāmiyyah II.,74.

${ }^{8}$ Abdur Rozak dan Rosihan Anwar, Ilmu Kalam(Bandung: CV. Pustaka Setia, 2011), 163.

${ }^{9}$ KH.Ach. Masduki, Konsep Dasar Pengertian Ahl al-Sunnah Waal-Jamā'ah (Surabaya: Pelita Dunia, 1994), 81.

${ }^{10}$ Harun Nasution, Teologi Islam, 33.
} 
baik atau buruk secara totalitas dinisbatkan pada manusia itu sendiri. Senada juga dengan statemen yang dilontarkan oleh Ibnu Hajar sebagaimana yang dinukil olehAbu Lubābah Husein dalam Hadis al-Sari bahwa kaum Qadariyah adalah orang yang berkeyakinan bahwa perbuatan jelek seorang hamba adalah dirinya sendiri. ${ }^{11}$

Penganut Qadariyah menganut paham kebebasan berkehendak dengan meniadakan kekuasaan Tuhan baik dalam perbuatan moral manusia, keadilan maupun dalam menanggapi pemaafan terhadap pelaku dosa.Jadi paham Qadariyah menolak penisbatan kepada Tuhan terlepas apakah yang berhubungan dengan dasar hukum dan perbuatan. ${ }^{12}$

Orang yang pertama kali mengeluarkan pendapat tentang takdir dalam dunia Islam adalah seorang Nasrani dari Iraq yang masuk Islam, namun kemudian kembali pada agamanya semula.Ia bernama Abū Yūnus Sansawaih. Pendapatnya membuat Ma'bad al-Juhāni terinspirasi untuk kemudian mengikuti pendapat-pendapatnya. Selanjutkan diteruskan oleh Ghulaim al-Damashqii, sehingga dalam sejarah ketiga orang tersebut dinyatakan sebagai tiga serangkai yang menjadi pioner berkembangnya paham Qadariyah. ${ }^{13}$

Menurut Qadariyah bahwa segala tingkah laku manusia dilakukan atas kehendak sendiri.Manusia mempunyai kewenangan untuk melakukan segala perbuatannya atas kehendaknya sendiri baik itu perbuatan baik maupun berupa perbuatan jahat.Karena itu manusia berhak mendapatkan pahala atas kebaikan yang dilakukannya dan juga berhak memperoleh hukuman atas kejahatan yang dilakukannya.Pahala atas kebaikan yang dilakukan tersebut berupa surga dan hukuman atau balasan atas pelaku kejahatan adalah neraka.Hal ini merupakan manifestasi dari pilihan manusia itu sendiri tidak ada hubungannya dengan takdir Allah Swt. ${ }^{14}$

Faham takdir dalam pandangan Qadariyah adalah ketentuan Allah yang diciptakan-Nya untuk alam semesta beserta seluruh isinya, dan segala sesuatu yang terjadi merupakan wujud dari hukum alam yang lumrah disebut dengan Sunnatullah. ${ }^{15}$ Pandangan Qadariyah tentunya sangat berlawanan dengan pandangan bangsa Arab saat itu bahwa segala sesuatu yang terjadi pada manusia sebelumnya telah tercatat dalam ketentuan Allah.

Perbedaan yang muncul diakibatkan bangsa Arab dulu hidup dengan tergantung pada kedaan alam, berpasrah pada keadaan yang

\footnotetext{
${ }^{11}$ Abu Lubābah Husaīn, Pemikiran Hadis Mu’tazilah(Jakarta: Pustaka Firdaus, 2003), 24.

${ }^{12}$ Fazlur Rahman, Revival and Reform in Islam, terj. Aam Fahmi (Jakarta: Raja Grafindo Persada, 2001), 76.

${ }^{13}$ Abu Lubābah Husaīn, Pemikiran HadisMu'tazilah., 24.

${ }^{14}$ Abdur Rozak dan Rosihan Anwar, Ilmu Kalam, 161.

${ }^{15}$ Ibid., 161.
} 
walaupun penuh dengan padang pasir, tetapi mereka menerima dengan apa adanya (fatalistik)-dalam hal ini sudah terdapat pengaruh Jabariyah- oleh karenanya bangsa Arab sangat menentang terhadap paham Qadariyah, karena dianggap menentang terhadap ajaran Islam. Hal ini dapat lihat dengan munculnya hadis mengenai Qadariyah yang menyatakan bahwa kaum Qadariyah merupakan Majuzinya umat Islam, dengan kata lain merupakan paham sesat. ${ }^{16}$ Dengan perbedaan pandangan inilah yang kemudian dalam perkembangannya muncul golongan Jabariyah, sebagai tandingan untuk mementahkan paham Qadariyah.

Aliran Qadariyah berpendapat bahwa tidak ada alasan yang tepat menyandarkan segala perbuatan manusia kepada perbuatan Tuhan. Pendapat ini diperkuat dengan dalil-dalil Shar'î yang terdapat dalam alQur'an yang selama ini dijadikan pijakan secara legal-formal oleh aliran Qadariyah, yaitu dalam surat al-Kahfiayat 29 yang berbunyi:

وقل الحق من ربكم فمن شاء فليو ه من ومن شاء فليكفر 17

"Katakanlah kebenaran dari tuhanmu, barang siapa yang mau berimanlah dia dan barang siapa yang ingin kafir biarlah ia kafir".

Dalam suratal-Ra'ad ayat 11 juga disebutkan yaitu:

ان اله لا يغيرما بقوم حتى يغيروا ما بانفسهم 18

"Sesungguhnya Allah tidak mengubah keadaan suatu kaum, kecuali mereka dapat merubahnya sendiri".

Selanjutnya dalil naq $\bar{i}$ dalam surat al-Nisā' ayat 111:

$$
\text { ومن يكسب اثما فانما يكسبه على نفسه } 19
$$

"Dan barang siapa melakukan suatu dosa, sesungguhnya ia melakukannya untuk merugikan dirinya sendiri".

Beberapa ayat al-Qur'an yang telah dipaparkan di atas secara tekstual mengandung pengertian bahwa manusia mempunyai daya dan kekuatan yang dominan, artinya memiliki kebebasan mutlak dalam bertindak. Namun kebebasan tersebut akan memunculkan konsekuensi logis sebagai akibat dari tindakan yang telah dipilih atau dilakukan sendiri. Jika manusia memilih perbuatan yang baik maka konsekuensinya akan mendapatkan kebaikan, sebaliknya bilamana manusia memilih jalan keburukan maka nantinya akan memperoleh keburukan pula. Inilah inti ajaran dari golongan Qadariyah.

Berkaitan dengan hal di atas menurut aliran Qadariyah Allah membekali manusia sejak lahirnya dengan qudrat dan irädat; suatu kemampuan untuk mewujudkan perbuatannya sendiri dengan akal dan ajaran agama sebagai pedoman dalam melakukan perbuatan-perbuatan

${ }^{16}$ Harun Nasution, Teologi Islam,34.

${ }^{17} \mathrm{Al}-\mathrm{Qur}$ 'an, 18:29.

${ }^{18}$ Ibid., 13:11.

${ }^{19}$ Ibid., 4:111. 
tersebut. Sehingga dengan demikian manusia memperoleh balasan dari apa yang telah diperbuat. ${ }^{20}$

Aliran Qadariyah menempatkan porsi rasio di atas ketentuan takdir Allah, sehingga segala sesuatu yang terjadi pada diri manusia adalah sesuai dengan kehendak manusia itu sendiri, maka akibatnya akan kembali pada manusia yang melakukan perbuatan tersebut sebagai konsekuensinya. Tidak hanya itu, aliran Qadariyah juga melegitimasi pemikirannya pada teks alQur'an sebagai landasan legal formal untuk memperkuat pendapatpendapatnya, sebagaimana yang telah disebutkan di atas. Dapat dinyatakan bahwa golongan Qadariyah tidak hanya sekadar memperioritaskan akal akan tetapi juga menempatkan wahyu sebagai legitimasi.Oleh karena itu apapun pemikiran yang dihembuskan oleh aliran Qadariyah tidak bisa dipersalahkan secara serta merta, karena argumentasi yang diberikan sungguh berlandaskan pada wahyu ilahi, terlepas dari pendapatnya yang sepihak.

\begin{abstract}
Aliran Jabariyah
Disamping aliran Qadariyah juga terdapat aliran Jabariyah yang memiliki pemikiran berbeda secara diametral.Pemikiran yang disinyalir tidak dapat dipertemukan titik tengahnya, karena memiliki argumentasi yang cukup kuat dan bersifat legitimate.Artinya pendapat-pendapatnya juga di legitimasi dengan ketentuan ayat-ayat al-Qur'an.

Tokoh utama Jabariyah adalah Jaham Ibn Șafwān. Dilihat dari namanya golongan ini sering juga disebut Jahmiyah. Jaham mendirikan paham Jabariyah pada abad ke-2 Hijriyah.Jahm berasal dari Persia, setelah ia masuk Islam kemudian menjadi pegawai al-Harith Ibn Suraij yang merupakan kelompok bendera hitam yang memberontak pada bani Umayah.Pada tahun $131 \mathrm{H}$, Jahm mati terbunuh dalam peperangan melawan tentara Khalifah bani Ummayah,kemudian estafet kepemimpinannya dipegang oleh beberapa muridnya. ${ }^{21}$

Harun Nasution menyatakan bahwa paham Jabariyah pertama kali diungkapkan dalam Sejarah Teologi Islam oleh al-Ja'd Ibn Dirhām, tetapi yang menyiarkannya adalah Jaham Ibn Șafwān dari Khurasan. Jahm yang terdapat dalam aliran Jabariyah ini sama dengan Jahm yang mendirikan aliran al-Jahmiah dalam kalangan Murji' ah. ${ }^{22}$

Dilihat dari perspektif sejarah, sebenarnya bangsa Arab telah menganut aliran Jabariyah walaupun tidak secara formalistis dalam bentuk golongan (sekte). Secara realistis dalam kehidupan seluruhnya sangat
\end{abstract}

${ }^{20}$ Tim Penyusun, Tauhid Ilmu Kalam (Pamekasan: STAIN,tt), 146.

${ }^{21}$ Yusran Asmuni, Dirāasah Islāmiyyah II., 75. M. Romli Arief, Kajian Ahl alSunnah, 69.

${ }^{22}$ Harun Nasution, Teologi Islam,35. 
bergantung pada keadaan yang timbul pada saat itu, misalnya keadaan alam yang penuh dengan padang pasir tandus, hidup sederhana, jauh dari pengetahuan, tanah dan gunung yang gundul serta keadaan lain yang mereka terima secara fatalistis, pasrah terhadap apa yang telah diberikan oleh Tuhan. Tidak terdapat upaya apapun untuk mengadakan perbaikan hidup secara mandiri yang mengandalkan kemampuan dirinya. ${ }^{23}$ Fenomena seperti ini dapat dipastikan genealogi pemikiran Jabariyah sudah ada sejak bangsa Arab Jahiliyah atau bahkan semenjak manusia berpijak di bumi Allah ini.Karena kehidupan manusia pada zaman purba tergantung pada kondisi alam sekitar (food gatring) sehingga menuntut mereka untuk hidup secara berpindah-pindah (nomaden) menyesuaikan dengan ketersediaan sumber makanan pada lingkungan yang ditempati.Hal ini menunjukkan sifat pasrah dan ketundukan pada keadaaan yang terjadi.Sifat inilah yang menunjukkan pada sifat aliran Jabariyah.

Dalam perkembangannya golongan Jabariyah muncul sebagai reaksi atas munculnya golongan Qadariyah yang sangat ekstrem.Hal ini mengimbangi atau memberikan wacana tanding terhadap pendapatpendapat yang telah dilontarkan oleh Qadariyah yang dengan secara gamblang menafikan peran Allah swt.dalam segala perbuatan manusia. Oleh karena itu golongan ini kemudian diberluaskan oleh Jaham Ibn Șafwān.

Golongan Jabariyah pada mulanya merupakan kelompok aliran teologis, bersifat ketuhanan dan berhubungan dengan aqidah tauhid, kemudian berkembang dan merambah ke berbagai dimensi keilmuan keislaman yang lain diataranya: tasawwuf, akhlak, filsafat, fiqih dan tafsir. Perkembangan selanjutnya membentuk ideologi Jabariyah yang dijadikan pijakan utama dalam memahami agama dan realitas. ${ }^{24}$

Istilah jabar dapat diartikan menolak adanya perbuatan dari manusia dan menyandarkan semua perbuatan kepada Allah. Berdasarkan pengertian ini Jabariyah ada dua bentuk yaitu: (1) Jabariyah Murni, yang menolak adanya perbuatan berasal dari manusia dan memandang manusia tidak mempunyai kemampuan untuk berbuat; dan (2) Jabariyah Pertengahan yang moderat, mengakui adanya perbuatan dari manusia namun perbuatan manusia tidak membatasi. Orang yang mengaku adanya perbuatan dari makhluk ini yang mereka namakan "kasab" bukan termasuk Jabariyah. ${ }^{25}$

Terdapat perbedaan yang mencolok antara Jabariyah Ekstrem (murni) dengan Jabariyah Moderat yaitu terletak pada ada tidaknya peranan manusia dalam setiap perbuatannya.Jabariyah Ektrem sangat menafikan peran manusia, artinya manusia tidak mempunyai daya atau kekuatan, kehendak apapun kecuali atas kehendak Allah swt..Sedangkan Jabariyah

\footnotetext{
${ }^{23}$ Ibid., 33 .

${ }^{24}$ M. Romli Arief, Kajian Ahl al-Sunnah Waal-Jama'ah Tinjauan Historis, 72.

${ }^{25}$ Al-Shahrastanī, Al-Milāl wa al-Nihāl, 71.
} 
Moderat masih mengakui adanya peran manusia didalam perbuatannya, walaupun peran yang diberikan manusia adalah atas kehendak Allah.Hal inilah kemudian memunculkan istilah kasab (aquisition).Menurut paham kasab bahwa manusia itu tidaklah majbür (dipaksa oleh Tuhan), tidak seperti wayang yang dikendalikan oleh dalang dan tidak pula menjadi pencipta perbuatan, tetapi manusia itu memperoleh perbuatan yang diciptakan oleh Tuhan. ${ }^{26}$

Al-Shahrastanimengklasifikasikan golongan Jabariyah menjadi tiga aliran, yaitu (1) Al-Jahmiyah, (2) Al-Najariyah dan (3) Al-Dirariyah. ${ }^{27}$

Pertama, Aliran Al-Jahmiyah. Pendiri aliran ini adalah Jahm Ibn Safwān $(124 \mathrm{H})$. Dia dianggap sebagai pengikut Jabariyah Murni yang memiliki pemahaman bahwa Allah yang menguasai seluruh perbuatan manusia, berupa perbuatan baik maupun perbuatan buruk. Diantara pemahaman Al-Jahmiyah antara lain: (a) makhluk tidak boleh memiliki sifat yang sama dengan sifat Allah dan kalau terjadi berarti menyamakan Allah dengan makhluk-Nya. (b) ia mengakui ilmu Allah bukan pada sifat dzat-Nya, sesuatu yang belum diciptakan Allah tidak diketahui Allah (c) manusia tidak memiliki kekuatan sedikitpun, manusia tidak dapat dikatakan mempunyai kemampuan. (d) manusia akan kekal baik di surga maupun neraka. (e) siapa yang sudah memiliki ma'rifah kepada Allah, kemudian ia mengingkari Allah dengan lisannya maka tidak dikatakan kafir. ${ }^{28}$

Kedua, Aliran al-Najariyah. Pendiri aliran ini adalah al-Husein Ibn Muhammad al-Najār $(230 \mathrm{H})$ dan ia termasuk tokoh Mu'tazilah yang paling banyak menggunakan rasio. Sehingga pemahamannya banyak kesamaan dengan Mu'tazilah. Diantara pemahamannya yaitu menolak adanya sifat 'Ilmu, Qudrat, Irädat, Sama', Hayat dan Bașar bagi Allah, namun mereka sependapat dengan aliran Șifatiyah yang mengatakan semua perbuatan merupakan ciptaan Allah. Aliran Najariyah juga mengakui adanya paham kasab yaitu usaha manusia, bahwa manusia mempunyai peran dalam berbuat baik atau buruk, namun peran tersebut tidak terpas dari campur tangan Allah. ${ }^{29}$

Ketiga, Aliran al-Ḍirāriyah. Pendiri aliran ini adalah Dirāar ibn Amr dan Hafșūl al-Fard, keduanya sependapat dengan sifat Allah, namun kedua berkata bahwa Allah Maha Mengetahui dan Maha Kuasa. Aliran ini juga menyatakan bahwa perbuatan manusia adalah ciptaan Allah pada hakikatnya, namun manusia yang menggunakannya. Dalam hal

\footnotetext{
${ }^{26}$ Abdal-Rozāk dan Rosihan Anwar, Ilmu Kalam, 160.

${ }^{27}$ Al-Shahrastanī, Al-Milāl wa Al-Nihāl,71.

${ }^{28}$ Ibid., 71-72.

${ }^{29}$ Ibid., 73 .
} 
kepemimpinan aliran ini juga berpendapat bahwa pemimpin yang harus lebih diutamakan yaitu dari ket urunan Rasulullah saw. ${ }^{30}$

Dasar ideologis yang digunakan oleh golongan Jabariyah yaitu ayat al-Qur'an yang sudah dipahami gamblang yaitu dintaranya dalam surah alAn'ām ayat 112:

"Mereka sebenarnya tidak akan percaya, sekiranya Allah tidak menghendaki".

Dalam al-Hadid ayat 22 juga disitir:

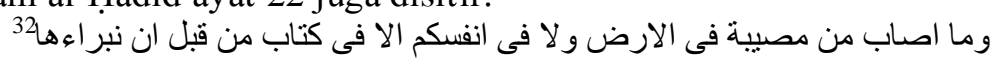

"Tidak ada bencana yang menimpa bumi dan diri kamu, kecuali telah ditentukan di dalam buku sebelum kami wujudkan".

\section{Integrasi Pemikiran Qadariyah dan Jabariyah}

Perbedaan pemikiran antara aliran-aliran keislaman sebetulnya terletak pada penempatan porsi akal dan wahyu, mana yang lebih diperioritaskan dan mana yang lebih dikesampingkan. Apabila porsi akal yang ditempatkan pada kedudukan yang lebih tinggi maka akan lebih mengesampingkan porsi wahyu atau sebaliknya bilamana wahyu yang dijadikan skala prioritas, maka bukan hal yang mustahil akan menempatkan porsi akal pada kedudukan yang inferior.

Pemikiran kaum Qadariyah lebih menempatkan akal pada porsi yang superior, sehingga mengesampingkan yang lainnya, termasuk takdir Allah.Kehendak akal menjadi jujukan utama manusia dalam melakukan kehendaknya, tidak sedikitpun terkait dengan ketentuan Allah SWT.Adapun turunan (underbow) dari aliran ini adalah Mu'tazilah yang juga menempatkan posisi akal sebagai segala-galanya dalam pemikiran keislaman (teologi). Di satu sisi memang aliran ini memberikan sumbangsih yang cukup besar dalam ranah pemikiran Islam, karena penggunaan akal sangat diperlukan dalam proses ijtihadi atau mengiterpretasikan teks-teks keagamaan agar dapat dipahami secara konteksktual sesuai sosio kultur yang berkembang.Disamping itu umat Islam agar tidak tertutup atau tidak konservatif dalam hal pemikiran. Dengan kata lain, penggunaan rasio dalam memahami tekstualitas keagamaan dapat menjauhkan dari tertutupnya pintu ijtihad.

Namun, pada sisi yang lain penggunaan akal yang tidak berpijak sama sekali pada teks-teks keagamaan akan memunculkan pemikiran yang melenceng dari kebenaran, bahkan cenderung berujung pada liberalisme yaitu pemahaman yang cenderung bebas kebablasan jauh dari sumber

\footnotetext{
${ }^{30}$ Ibid., 75.

${ }^{31}$ Al-Qur'an, 6:112.

${ }^{32}$ Ibid., 57:22.
} 
kebenaran yang hakiki (wahyu ilahi) yang pada ending-nya berakhir pada kesesatan. Pemahaman seperti ini akan sangat berbahaya bagi umat Islam secara mayoritas, apalagi persoalannya pada ranah teologi akan menimbulkan kemusyrikan dan kesesatan dalam memahami ajaran keagamaan.

Aliran Jabariyah memiliki pemikiran yang terbalik dari pemikiran Qadariyah.Mereka cenderung menempatkan posisi akal pada kedudukan inferior.Dan mendudukkan teks pada posisi yang tinggi, bersandar secara mutlak pada ketentuan Allah.Manusia dianggap tidak memiliki kuasa sedikitpun dalam menentukan kehendaknya.Seluruh kehendak manusia ditentukan secara mutlak oleh kehendak Allah SWT.Pendapat-pendapat yang disampaikan oleh kaum Jabariyah bukan hanya sekedar statemen saja tanpa landasan.Akan tatapi mereka juga melegitimasi pendapatnya dengan ketentuan al-Qur'an seperti yang telah dijabarkan di muka.

Apabila melihat historisitas aliran-aliran keislaman tentu saja tidak terlepas dari persoalan politik kekuasaan yang telah terjadi pada masa Rasulullah saw., para Sahabat, para Tabi'in sampai pada masa Daulah Islamiyah. Munculnya aliran keislaman puncaknya diakibatkan oleh peristiwa tahkim (albitrase) yang terjadi pada Khalifah Ali bin AbịTalib dalam perang Siffin, yang kemudian kekuasan diambil alih oleh Muawiyah bin Abī Sofyān. Sehingga peristiwa ini menimbulkan perpecahan secara politis, maka muncullah kaum Khawārij, Syi'ah, Qadariyah, Jabariyah, Murjiah, Mu'tazilah dan sebagainya. Diantara mereka muncullah keyakinan takfiri, yaitu keyakinan yang saling mengkafirkan antar-aliran yang notabene saling berbeda keyakinan dan pemikiran sebagai imbas dari konstelasi pilitik kekuasaan.Dari ranah sosial politik kekuasaan kemudian berimbas pada pemikiran keislaman terkait dengan teologi.Misalnya; masalah pelaku dosa besar, hari pembalasan, tauhid, pemahaman tentang Dzat Allah dan masalah lainnya yang relevansinya dengan persoalan keislaman.

Perseteruan pemikiran yang terjadi diantara aliran keislaman khususnya dalam pembahasan ini adalah Qadariyah dan Jabariyah menunjukkan heterogenitas pemikiran yang tidak dapat dipersatukan satu sama lain. Karena masing-masing memiliki persepsi bahwa pendapat golongannya sendiri yang paling benar. Mereka mempunyai sifat fanatisme (asabiyah) yang berlebihan. Dalam mainstream mereka bahwa pemikiran golongan lain dianggap salah sedangkan pendapat dirinya yang paling benar. Aliran Qadariyah menganggap bahwa manusia adalah penentu kehendak secara totalitas. Sedangkan aliran Jabariyah justru menganggap sebaliknya bahwa manusia tidak mempunyai kuasa apapun dalam menentukan kehendaknya, seluruhnya menjadi kehendak sang Maha Pencipta.Kedua pemikiran inilah yang tidak dapat dipersatukan sehingga menimbulkan perseteruan pendapat. 
Sebenarnya apabila dilakukan upaya untuk mengintegrasikan pemikiran kedua aliran Qadariyah dan Jabariyah maka bukan tidak mungkin untuk bisa dipertemukan. Namun berangkat dari sifat egoistis dan sifat pembenaran antara keduanya sehingga sampai kapanpun tidak akan bisa disatukan.Perlu adanya apresiasi secara mendalam terhadap aliran keislaman yang menjadi mediator dan dapat mengitegrasikan kedua pemikiran yang saling berseberangan yaitu aliran Ash'ariyah yang menjadi benteng ideologi Ahlussunnah Waljama'ah, serta menjadi penyelamat dari ideologi-ideologi sesat diantara aliran-aliran keislaman.

Aliran Ash'ariyah berawal dari adanya golongan Mu'tazilah yang selalu mempertuhankan rasio sebagai patokan dalam menentukan kehendak manusia. Bahkan dijadikan sebagai ideologi Negara pada masa Dinasti Abbasiyah dalam kepemimpinan khalifah al-Makmūn. Tidak hanya itu, penguasa juga melakukan intimidasi terhadap para ulama pada masa itu yang tidak patuh dan tidak meyakini terhadap paham Mu'tazilah, sehingga Imam Ibnu Hanbal menjadi korban penganiayaan dan pemenjaraan oleh penguasa al-Makmūn. ${ }^{33}$ Untuk membendung paham Mu'tazilah tersebut maka muncul paham Asy'ariyah sebagai penetrasi dari pemikiran Mu'tazilah yang diusung Abū al-Hasan al-'Ash'arì dan Abū Manșūr alMāturidi di Samarkand. ${ }^{34}$ Pemikiran Ash'ariyah inilah yang menjadi pedoman dalam pemikiran teologi Ahlussunnah Waljma'ah karena dianggap pemikiran yang benar dan tidak melenceng dari ajaran Rasulullah dan para sahabat Nabi.Sampai dengan masa sekarang pemikiran moderat dari Ash'ariyah menjadi jalan tengah yang dapat mengitegrasikan kedua pemikiran yang saling bersebrangan secara diametral.Oleh karena itu ideologi Ash'ariyah tetap dipakai sebagai ideologi Ahlussunnah Waljama'ah yang dipedomani oleh kaum Sunni secara mayoritas.

\section{Epilog}

Sebagai kesimpulan dari pembahasan di atas yaitu bahwa terdapat dua aliran teologi yang memiliki pendapat dan pemahaman berbeda secara diametral.Aliran yang dimaksud adalah Qadariyah dan Jabariyah.Qadariyah memiliki i'tiqād bahwa manusia memiliki otoritas utuh atas segala tindaktanduk perbuatannya, tidak ada intervensi dari Qudrat dan Irādat Allah swt.Sedangkan Jabariyah justru memiliki pandangan yang sebaliknya, bahwa seluruh perbuatan manusia menyangkut baik atau buruk tidak terlepas dari Qudrat dan Irādat Allah.

\footnotetext{
${ }^{33}$ Nukman Abbas, al-Asy'ari: Misteri Perbuatan Manusia dan Takdir Tuhan (Jakarta: Penerbit Erlangga, t.th), 103.

${ }^{34}$ Muhammad Abū Zahrah, Tarikh al-Mazāhib al-Islamiyyah, terj.Abdurrahman Dahlan danAhmad Qarib, Aliran Politik dan Aqidah dalam Islam (Jakarta: Logos Publishing House, 1996), 189.
} 
Perbedaan yang muncul dikarenakan mereka memiliki dalil-dalil yang sama-sama kuat baik secara rasio maupun dalil naqli sebagaimana yang telah tercantum teks-teks al-Qur'an.Dua hal itulah yang kemudian oleh mereka dijadikan sebagai landasan idelogis, sehingga secara ekstrim mereka menganggap benar pendapatnya masing-masing.

Sebagai solusi yang mampu mengitegrasikan kedua pemikiran yang saling bertentangan yaitu golongan Ash'ariyah sebagai ideologi dari Ahlussunnah Waljamaah yaitu aliran yang sesuai dengan ajaran Rasulullah saw. dan para sahabatnya. Sampai sekarang ideologi ini tetap dipakai oleh kaum muslimin secara mayoritas. Wallahu A'lam bi al-șawāb.

\section{Daftar Pustaka}

Abdul Qahir, Abu Mansur ibn Tahir al-Baghdadi. al-Farqu bayna al-Firaq. Mesir: Maktabah Ibn Sinā, t.th.

Abbas, Nukman Abbas. al-Asy'ari: Misteri Perbuatan Manusia dan Takdir Tuhan. Jakarta: Penerbit Erlangga, t.th.

Abū Zahrah, Muhammad.Tarikh al-Mazāhib al-Islamiyyah, terj.Abdurrahman Dahlan dan Ahmad Qarib, Aliran Politik dan Aqidah dalam Islam.Jakarta: Logos Publishing House, 1996.

Ahmad ibn Muhammad ibn Ibrahim ibn Khalliqan, Wafayāt al-A'yān,. Beirut: Dār Șādir, 1971.

Arief, M. Romli. Kajian Ahl al-Sunnah Waal-Jamā'ah Tinjauan Historis. Jombang: Unhasy Press, 2005.

Asmuni, Yusran. Dirāsah Islāmiyyah II. Jakarta: PT. Grafindo Persada, 1996.

Husain, Abu Lubabah. Pemikiran Hadis Mu'tazilah. Jakarta: Pustaka Firdaus, 2003.

Masduki, Ach. Konsep Dasar Pengertian Ahl al-Sunnah Waal-Jamā'ah. Surabaya: Pelita Dunia, 1994.

Nasution, Harun. Teologi Islam Aliran-Aliran Sejarah Analisa Perbandingan . Jakarta: Universitas Indonesia, 2002.

al-Qasimi, Jamaluddin. Târikh al-Jahmiyyah wa al-Mu'tazilah. Beirut: Mu'assasah al-Risālah, 1989.

Rahman, Fazlur. Revival and Reform in Islam, terj. Aam Fahmi. Jakarta: Raja Grafindo Persada, 2001.

Rozak, Abdur dan Rosihan Anwar.Ilmu Kalam. Bandung: CV. Pustaka Setia, 2011.

Al-Shahrastanì.Al-Milāl wa al-Nihāl. Terj. Asywadie Syukur. Surabaya: PT. Bina Ilmu, 1995.

Syalabi, A. Sejarah Dan Kebudayaan Islam. Jakarta: Pustaka Alhusna Baru, 2008.

Syihab, A. Akidah Ahl al-Sunnah. Jakarta: Bumi Aksara, 1998.

Tim Penyusun, Tauhid Ilmu Kalam. Pamekasan: STAIN,tt. 